\title{
Anthropometric parametrization of Uniforms for Armed Forces
}

\author{
Inga Dāboliṇa, Ausma Viḷumsone and Eva Lapkovska \\ Riga Technical University, FMSAC, Institute of Design Technologies, \\ Kippsalas street 6-220, Riga, LV-1048, Latvia; E-mail: inga.dabolina@rtu.lv
}

\begin{abstract}
Planning manufacture of uniforms decisions must be taken as to how many and in what size a particular model series should be manufactured, how they should be labeled and to what body-dimensions garment sizes should correspond. The purpose of anthropometric parametrization is to introduce garment size classification for mass production clothing, so as to representatively depict wearers' body figure diversity. It is in the interests of manufacturers (design time and costs, logistics etc.) and buyers/procurement service alike to confine themselves with a minimum garment sizes and to use a possibly less complicated garment size classification. The aim of this research is to gather different impact factors for anthropometric parametrization for Uniforms of Armed Forces.

Research is formed from anthropometric data and end user survey exploring data set of 150 soldiers. Anthropometrics are performed by non-contact anthropometric methods (3D anthropometrical scanner Vitus Smart XXL® is used in the study), data processing automation systems, pattern making CAD/CAM systems, etc. National Armed Forces (NAF) technical specification provides for manufacture of a wide range of garment sizes (by height indifference interval of 6 $\mathrm{cm}$ ). Manufacturers labeling system and charts of finished products are subjected to comparative analysis and evaluation of corresponding standard recommendations is included.

The study indicates the need to optimize the currently used anthropometry method in the Latvian Army, anthropometric data registration and application, thus improving the performance of military personnel and the procurement process and the use of resources, thus promoting resource planning and environmental protection. Also improvements are needed in uniform labeling and instructing of the military personnel on selection of uniform and equipment components.
\end{abstract}

Proper anthropometric parametrization and labeling of Uniforms for Armed Forces would minimize expenses of Uniforms as well as the negative waste impact to the environment.

Keywords: anthropometry, clothing industry, design automation/CADCAM, mass customization.

\section{INTRODUCTION}

The most important problems with designing and producing uniforms for National Armed Forces (NAF) is the lack of proper anthropometric data of wearers - soldiers. Generally procedure of ordering and supplying uniforms are based on normal distribution (Gaussian function) with standard deviation +/- 10\%. EN 13402 [1] is a European standard for labelling clothes sizes. It is based on body dimensions, measured in centimeters. It replaces many older national dress-size systems in popular use before the year 2007. Cabinet of Ministers of the Republic of Latvia Regulation No.519 [2], paragraph 25 reads that uniforms are issued corresponding to garment sizes based on anthropometric measurements, which are taken upon person joining the service, and later every two years, while paragraph 28 stipulates that tailoring of field uniforms shall be organized on an individual basis, if soldier anthropometric measurements do not correspond to the standard size. However, neither the Latvian Republic Ministry of Defense nor other uniformed services regulatory technical documents contain any definite references to the requirements of these "standards" and availability, procedure of obtaining anthropometric data standardization [3].

The right clothing and equipment is vital importance to the survival and effectiveness of military personnel [4]. One of initial aspects is appearance and fit of uniforms [5] and now the information necessary to ensure it can be obtained and processed using non-contact technologies.

This anthropometric research [6] was carried out by using data of the NAF units. According to the National Defense Concept, the number of NAF personnel in professional service does not exceed 5,800 , which was respectively equated with the general group in the anthropometric research. The sample set consisted of at least 3350 measurements. Research results confirmed the conformity of the NAF personnel anthropometric data to the normal distribution.

End users claims about uniforms - fitting of field uniforms are partly weak, defects such as seamstitching splits and fabric splits are often found in the area of the crotch during the use of soldiers' trouser. 
Therefore, the aim of the research in purpose to do anthropometric parametrization for Uniforms of Armed Forces is to identify potential reasons for defects by analyzing the fitting of the products as well as the design and the wearing habits of trousers.

\section{MATERIALS AND METHODS}

\section{A. Anthropometrics - 3D Scanning}

In the research, measurements have been gathered by Vitus Smart XXL human body 3D scanner, which conforms to the ISO 20685 standard. This equipment is designed to capture the surface of the human body in a twelve seconds. The scanning volume is $210 \mathrm{~cm}$ in height by $100 \mathrm{~cm}$ by $110 \mathrm{~cm}$ in depth and width. Resolution in $\mathrm{X}, \mathrm{Y}$, and $\mathrm{Z}$ is 27 points in $\mathrm{cm}$ in the middle of the scanning base for human subjects. 3D Human Body Scanner uses optical triangulation as the basis for measurement extraction. For this purpose, combination of camera and laser (laser sensor) is used. The lasers are switched on (pulsed) when the measurement begins. During the measurement, the slides travel vertically at a defined speed.

Standard anthropometry (traditional contact methods) dimensions are measured from one point on the body (or fixed surface such as the floor) to another. In the case of circumferences, the dimension is measured around a part of the body at a specified level. These measurements are taken with specific instruments: anthropometer, measurement tape, caliper.

Principal component analysis was used to create a plan for anthropometric data gaining for end-user group. The results of this study showed that there are differences in fit to the test person of these prototypes (all selected in size $\mathrm{M}$ ), also clarified scenario to measurement activities to be gathered from end-user group.

3D human body scanning and measuring activities of end-user group has been held.

The prerequisite for reliable body measurements is the correct position and posture of the subject during the scanning process. Instructions about the correct posture, both verbally and by means of an illustrated poster and presentation was given. Also anthropometrist checked out the position before scanning starts. The correct scanning posture was defined as follows: The end users stands on the scanner platform with his or her feet on "footprints" painted on the platform. The soldier forms fists, slightly bends the arms at the elbows, and positions the hands slight away from the hips. The subject looks straight ahead with the head held in a position to the Frankfurt plane. The soldier breathes normally and stands relaxed without flexing his or her muscles.

All end users were asked to wear tight-fitting underwear. Tight cap was used to produce smooth head shape if needed (hair-dress conditions).

\section{B. Measurements used}

Main measurements to analyse human body are three circumferences (bust, waist and hip circumference) and three lengths/heights (body height, waist height and crotch height).

Bust/chest girth - The circumference of the chest is measured across the bust point landmarks. The circumference is measured parallel to the standing surface (scanner code 4515). Waist girth - The circumference of the waist is measured in the height of the natural waist (if feasible). The natural waist height is determined by extracting a contraction point on the side. The circumference is measured parallel to the standing surface (scanner code 6510). Hip girth The circumference of the Hip is measured slightly underneath the buttock girth at a maximal girth location. The circumference is measured parallel to the standing surface (scanner code 7525). Body height - Vertical height from standing surface to the visual top of the head. The vertical distance is measured between the standing surface and the top of the head. Waist height - Vertical height of the waist girth (scanner code 6510) measurement to the standing surface. Crotch height - Vertical height of the crotch point to the standing surface (scanner code 0100).

\section{Experimental procedure}

The average statistical data of NAF soldiers in accordance with the general sample measurements are as follows: height $-179 \mathrm{~cm}$ (measurements of 3360 soldiers), chest circumference - $106 \mathrm{~cm}$ (measurements of 3351 soldiers), waist circumference - $94 \mathrm{~cm}$ (measurements of 3351 soldiers) [6]. One of the reasons for defects of clothes may be the unsuitability of clothing sizes with the dimensions of the human body. In the case of individual orders a correct measurement of the body is sufficient, but in mass production - careful planning of the type and number of sizes of a batch to be produced by taking into consideration anthropometric features of a consumer group is necessary.

In the framework of the process of 3D scanning of soldiers 150 uniform wearers were asked to indicate sizes of worn products (trousers and jackets of a field uniform). In the reports $87 \%$ (131) of respondents were able to indicate trouser sizes, however, types of labelling of sizes differ - 87\% (114) indicate one-size letter designations (XS-3XL). Moreover, 11\% (12) of them had doubts and indicated two labels (e.g. L/M), $6 \%$ (8) indicated two-dimensional numeric labelling (e.g.92/182), and only 7\% (9) two-dimensional letter designation, which had been implemented by the manufacturer and used in supply (e.g., L/REG). By taking into consideration that some of the respondents were unable to indicate trouser size (13\% (19)) and different types of labels, it was apparent that in the supply of this research group there was no common approach to labelling of clothing sizes to be worn or 
wearers themselves were confused over the types of labelling of trousers that may encourage receiving unsuitably-sized trousers.

In order to examine how appropriate the indicated sizes were with the body measures of each person (in total, 123 had a letter indicated), trouser sizes have been reviewed according to the measurement chart of the manufacturer on the basis of waist circumferences of wearers obtained in 3D scanning (primary key dimension). When these were compared it was apparent that $51 \%$ of trouser sizes (63) comply, according to primary key dimension - waist circumference. $31 \%$ (38) indicated a smaller size, but $18 \%$ (22) larger. As an overall result $49 \%$ (60) of the clothing worn by the 123 participants found that size is non-compliant with measurements of waist circumference (see Fig.1).

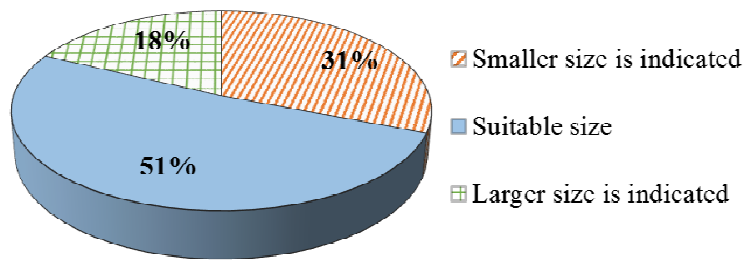

Fig. 1. Sizes of trousers - comparison of those indicated in the record and measurements in the charts of the manufacturer.

In the figure below (Fig.2.) differences are clearly demonstrated between the frequency of sizes (key dimension - waist circumference) developed according to reported and already reviewed measurements; moreover, more distinctive differences are observed exactly in the broadly represented size groups $\mathrm{M}, \mathrm{L}$ and XL.

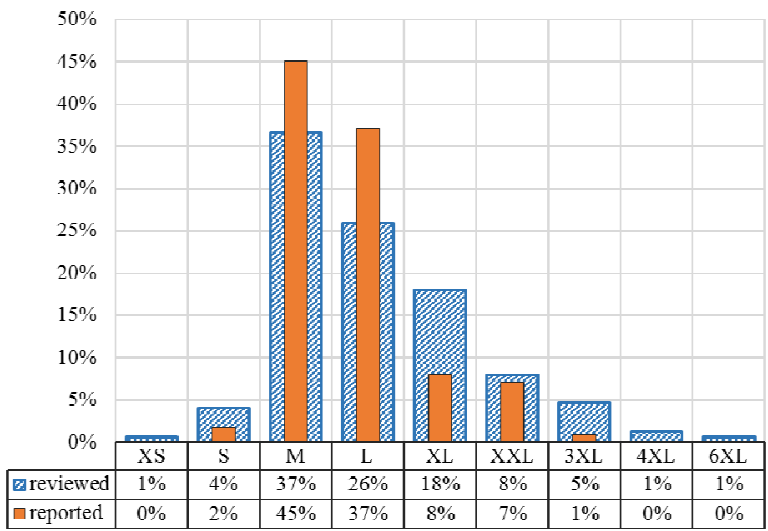

Fig. 2. Sizes of trousers - waist circumference frequency analysis.

When such unsuitability of trouser sizes with actual body measures exists, then a waist circumference is taken as a key dimension; it may be predicted in the framework of a specific research group as a reason for different defects during use.

Chest circumference, waist circumference, and body height are indicated in the measurement charts of the manufacturer's finished products as being the key dimensions for matching trouser size group and drawing up of a label for nether garments. If the application of a waist circumference is clearly justified in the design of trousers then there is no clear justification for chest circumferences to be included in a chart for drawing up of trouser sizes, as this body measurement is not used and does not affect the calculations of trouser design. The lengths of the inseam and side seam are classified by choosing body height as a key dimension (secondary).

As a result, finished trouser products are labelled by taking a waist circumference as the primary key dimension by classifying them into 7 sizes (XS-3XL), but as a secondary - body height, by classifying leg lengths (for inseam and side seam) into 7 lengths (2XSH-2XLO). In general, it provides 49 combined types of sizes $(7 \times 7=49)$.

This means that the inseam and side seam length will be determined by referring a test person to some body height interval. During anthropometric researches it has been established that persons referring to one body height interval may have different leg lengths i.e. proportion of legs in relation to a body height by classifying into, e.g. types of extra short legs, short legs, normal legs, long legs and extra-long legs.

\section{RESULTS AND DISCUSSION}

\section{A. Measurements}

When matching trousers/leg length intervals of the charts of the manufacturers determined by body height and leg length measurements (see chart), it is apparent that by individually examining existing leg lengths in some body height group not all wearers refer to these set intervals. However, averages are close to those set by the manufacturers.

In the framework of specific research group classification has been made according to body measurements and manufacturer charts by determining suitable labels for leg lengths (the other side of a two dimensional label). First, a label according to a body height has been found and afterwards according to measurement of inside leg length. (See example in Table I.)

Table I.

Measurement of inside leg length

\begin{tabular}{|l|l|l|l|l|}
\hline $\begin{array}{l}\text { Trouser } \\
\text { size }- \\
\text { recorded }\end{array}$ & $\begin{array}{l}\text { Body } \\
\text { height }\end{array}$ & $\begin{array}{l}\text { Range to } \\
\text { which refers } \\
\text { according to } \\
\text { body height }\end{array}$ & $\begin{array}{l}\text { Inside leg } \\
\text { length - } \\
\text { body } \\
\text { measurement }\end{array}$ & $\begin{array}{l}\text { Range to } \\
\text { which refers } \\
\text { according to } \\
\text { inside leg } \\
\text { length }\end{array}$ \\
\hline $\begin{array}{l}\text { XXL/ } \\
\text { REG }\end{array}$ & 181.0 & $\begin{array}{l}\text { REG } \\
(179-185)\end{array}$ & 79.6 & SHO (80) \\
\hline
\end{tabular}

When comparing, it has been established that in $72 \%$ (108) of the cases labels will not comply, i.e. a label will be affected by whether body height or inside leg length was taken as a key dimension of trouser length. Differences in leg proportions are also apparent when comparing frontal views of body images of people included in one body height interval (see Fig.3). 


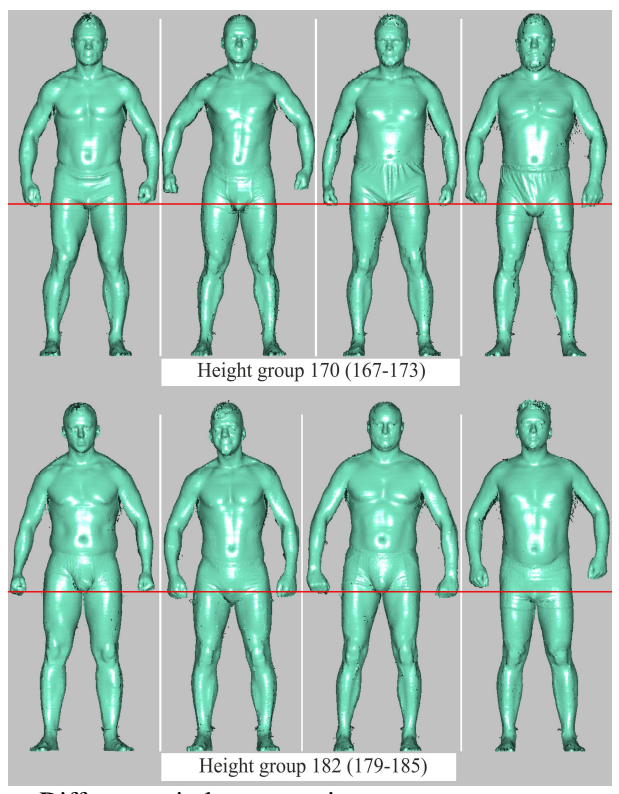

Fig. 3. Differences in leg proportions
It should be noted that according to instructions of the standard EN 13402-2:2002 (Size Designation of Clothes - Part 2: Primary and Secondary Dimensions] as key dimensions for men's trousers and shorts, a waist circumference (as a primary key dimension) and body height and/or inside leg length (as secondary key dimensions) should be used.

B. Tests on teared trousers

As one of the methods to gain proper result of analysis is to research existent product. Field Uniforms trousers from real field usage are analysed (seven samples).

When starting the experiment data on trouser sizes worn by the test persons was collected according to the manufacturer's chart (see Table II).

Table II.

Data on Sizes of Trousers Worn by Test Persons

\begin{tabular}{|c|c|c|c|c|c|c|c|c|c|c|c|}
\hline \multirow[b]{2}{*}{ No. } & \multirow{2}{*}{$\begin{array}{l}\text { No. in } \\
\text { general } \\
\text { list }\end{array}$} & \multirow[b]{2}{*}{ Sex } & \multirow[b]{2}{*}{ Age } & \multirow{2}{*}{$\begin{array}{l}\text { Trousers } \\
\text { size } \\
\text { (indicated) }\end{array}$} & \multicolumn{3}{|l|}{ Size } & \multicolumn{4}{|c|}{ Product control measurements } \\
\hline & & & & & $\begin{array}{l}\text { Size } \\
\text { group }\end{array}$ & $\begin{array}{l}\text { Chest } \\
\text { circumference }\end{array}$ & $\begin{array}{l}\text { Waist } \\
\text { circumference }\end{array}$ & $\begin{array}{l}\text { Waist } \\
(1 / 2)\end{array}$ & $\begin{array}{l}\text { Crotch } \\
\text { seam }(1 / 2)\end{array}$ & $\begin{array}{l}\text { Side } \\
\text { seam }\end{array}$ & Inseam \\
\hline 18 & 143 & M & 28 & XXL/REG & XXL & $116-120$ & $104-108$ & 53.5 & 42.5 & 112 & 82 \\
\hline 19 & 144 & M & 27 & XXL/REG & XXL & $116-120$ & $104-108$ & 53.5 & 42.5 & 112 & 82 \\
\hline 20 & 145 & M & 29 & $\mathrm{~L} / \mathrm{REG}$ & $\mathrm{L}$ & $100-104$ & $88-92$ & 45.5 & 38.5 & 110 & 82 \\
\hline 21 & 146 & M & 25 & $\mathrm{~L} / \mathrm{REG}$ & $\mathrm{L}$ & $100-104$ & $88-92$ & 45.5 & 38.5 & 110 & 82 \\
\hline 22 & 147 & M & 23 & $\mathrm{~L} / \mathrm{XSH}$ & $\mathrm{L}$ & $100-104$ & $88-92$ & 45.5 & 38.5 & 110 & 80 \\
\hline 23 & 148 & M & 23 & L/REG & $\mathrm{L}$ & $100-104$ & $88-92$ & 45.5 & 38.5 & 110 & 82 \\
\hline 24 & 149 & M & 22 & XL/REG & XL & $108-112$ & $96-100$ & 49.5 & 40.5 & 111 & 82 \\
\hline
\end{tabular}

In almost all labels (except No.22), test persons trouser lengths (in the charts see - inseam) are indicated as REG, i.e. Regular length of a value of 82 $\mathrm{cm}$, according to the charts. One of the hypothesis which has been put forward for the reason for defects is a choice of unsuitable inseam length. Firstly, on the basis of inside leg length suggested in standards as a necessity of separately selected secondary body measure for accurate determination of trouser size. Secondly, in the chart by summarising waist circumference, body height measurements and inside leg length measurements of test persons it has been apparent that there is a deviation of measurements of a wearer from the measurement chart made by the manufacturer and subsequent non-compliance with the chosen size.

In the summarised table (see Table III) size designations that have already been reviewed, as well as comments on established non-compliance are included.

Table III.

Summarised analysis data

\begin{tabular}{|c|c|c|c|c|c|c|c|c|c|c|}
\hline \multicolumn{11}{|c|}{ summarrsed anarysis data } \\
\hline No. & $\begin{array}{l}\text { Body } \\
\text { height }\end{array}$ & \multicolumn{2}{|c|}{$\begin{array}{l}\text { Trousers size } \\
\text { (indicated) }\end{array}$} & $\begin{array}{l}\text { Inseam } \\
\text { according to the } \\
\text { measurement } \\
\text { chart }\end{array}$ & $\begin{array}{l}\text { Inside leg } \\
\text { length - } \\
\text { measurement }\end{array}$ & .ొْ & $\begin{array}{l}\text { Waist } \\
\text { circumference } \\
\text { (according to } \\
\text { label) }\end{array}$ & $\begin{array}{l}\text { Waist } \\
\text { circumference - } \\
\text { measurement }\end{array}$ & \multicolumn{2}{|c|}{$\begin{array}{l}\text { Trousers size } \\
\text { (reviewed) }\end{array}$} \\
\hline \multirow[t]{2}{*}{18} & 181.0 & XXL & REG & 82 & 79.6 & -2.4 & $104-108$ & 117 & $3 \mathrm{XL}$ & $\mathrm{SHO}$ \\
\hline & \multicolumn{10}{|c|}{$\begin{array}{l}\text { Actual waist circumference does not comply with range of selected size XXL }(104-108 \mathrm{~cm}) \text { but it should be included in the next } \\
\text { size, } 3 \text { XL, instead. } \\
\text { If, according to a body height range }(179-185) \text { an inseam refers to REG range, then according to actual inside leg length a wearer } \\
\text { should be referred to the size SHO instead (by rounding up } 80 \text { not } 82 \text { as REG). } \\
\text { When changing a size, a wearer will obtain a nether garment with larger waist circumference and shorter inseam. }\end{array}$} \\
\hline
\end{tabular}




\begin{tabular}{|c|c|c|c|c|c|c|c|c|c|c|}
\hline No. & $\begin{array}{l}\text { Body } \\
\text { height }\end{array}$ & $\begin{array}{l}\text { Trous } \\
\text { (indic }\end{array}$ & & $\begin{array}{l}\text { Inseam } \\
\text { according to the } \\
\text { measurement } \\
\text { chart }\end{array}$ & $\begin{array}{l}\text { Inside leg } \\
\text { length - } \\
\text { measurement }\end{array}$ & 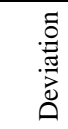 & $\begin{array}{l}\text { Waist } \\
\text { circumference } \\
\text { (according to } \\
\text { label) }\end{array}$ & $\begin{array}{l}\text { Waist } \\
\text { circumference - } \\
\text { measurement }\end{array}$ & \multicolumn{2}{|c|}{$\begin{array}{l}\text { Trousers size } \\
\text { (reviewed) }\end{array}$} \\
\hline \multirow[t]{2}{*}{19} & 188.4 & XXL & REG & 82 & 88.2 & +6.2 & $104-108$ & 104.2 & XXL & XLO \\
\hline & \multicolumn{10}{|c|}{$\begin{array}{l}\text { Waist circumference complies with charts of the manufacturer and size XXL. } \\
\text { According to the body height range (185-191), the inseam refers to LON range but even more according to actual inside leg } \\
\text { length a wearer should be rather referred to the size XLO instead (by rounding up } 88 \text {, not } 82 \text { as REG). } \\
\text { When changing a size a wearer will obtain a nether garment with a longer inseam. }\end{array}$} \\
\hline \multirow[t]{2}{*}{20} & 180.0 & $\mathrm{~L}$ & REG & 82 & 84.5 & +2.5 & $88-92$ & 84.5 & $\mathrm{~L}$ & LON \\
\hline & \multicolumn{10}{|c|}{$\begin{array}{l}\text { Waist circumference complies with charts of the manufacturer and size L. } \\
\text { If, according to the body height range (179-185), an inseam refers to REG range then, according to actual inside leg length, a } \\
\text { wearer should be referred to the size LON instead (by rounding up } 85 \text { not } 82 \text { as REG). } \\
\text { When changing a size a wearer will obtain a nether garment with a longer inseam. }\end{array}$} \\
\hline \multirow[t]{2}{*}{21} & 184.3 & $\mathrm{~L}$ & REG & 82 & 82.4 & +0.4 & $88-92$ & 84.3 & $\mathrm{~L}$ & REG \\
\hline & \multicolumn{10}{|c|}{$\begin{array}{l}\text { Waist circumference complies with charts of the manufacturer and size L. } \\
\text { REG size is correctly chosen for a wearer according to both the body height range (179-185) and actual inside leg length. }\end{array}$} \\
\hline \multirow[t]{2}{*}{22} & 166.6 & $\mathrm{~L}$ & $\mathrm{XSH}$ & 80 & 71.7 & -8.3 & $88-92$ & 88.4 & $\mathrm{~L}$ & $3 \mathrm{XSH}$ \\
\hline & \multicolumn{10}{|c|}{$\begin{array}{l}\text { Waist circumference complies with charts of the manufacturer and size L. } \\
\text { According to the body height range (161-167), an inseam refers to } 2 \mathrm{XSH} \text { range but even more according to actual inside leg } \\
\text { length a wearer should be referred to the size } 3 \mathrm{XSH} \text { instead (by rounding up } 72 \text { not } 78 \text { as XSH). } \\
\text { When changing a size a wearer will obtain a nether garment with a shorter inseam. }\end{array}$} \\
\hline \multirow[t]{2}{*}{23} & 175.6 & $\mathrm{~L}$ & REG & 82 & 76.3 & -5.7 & $88-92$ & 86.3 & $\mathrm{~L}$ & $\mathrm{XSH}$ \\
\hline & \multicolumn{10}{|c|}{$\begin{array}{l}\text { Waist circumference according to charts of the manufacturer and size L. } \\
\text { According to the body height range (173-179), an inseam refers to SHO range but even more according to actual inside leg length } \\
\text { a wearer should be referred to the size } 2 \mathrm{XSH} \text { instead (by rounding up } 76 \text { not } 82 \text { as REG). } \\
\text { When changing a size a wearer will obtain a nether garment with a shorter inseam. }\end{array}$} \\
\hline \multirow[t]{2}{*}{24} & 181.9 & XL & REG & 82 & 77.2 & -4.8 & $96-100$ & 99.3 & $\mathrm{XL}$ & $\mathrm{XSH}$ \\
\hline & \multicolumn{10}{|c|}{$\begin{array}{l}\text { Waist circumference complies with charts of the manufacturer and size XL. } \\
\text { If, according to a body height range (179-185), an inseam refers to REG range then, according to actual inside leg length, a } \\
\text { wearer should be referred to the size XSH instead (by rounding up } 77 \text { not } 82 \text { as REG). } \\
\text { When changing a size a wearer will obtain a nether garment with a shorter inseam. }\end{array}$} \\
\hline
\end{tabular}

In summarising existing and reviewed trouser sizes, it is apparent that in only one of seven cases there is compliance of product size with data on body measurements (No.21). In three cases it is apparent that by using only a body height as a secondary key dimension, a correct length is not always matched as an inside leg length. Values should be taken into consideration that may vary among persons within one body height range.
In addition, to clearly establish such noncompliance frontal views of body images (Fig.4) of test persons in scale are organised according to size groups of relevant clothes worn by indicating different heights of a seat seam. i.e. levels of inside leg lengths (classification according to the charts of the manufacturer).

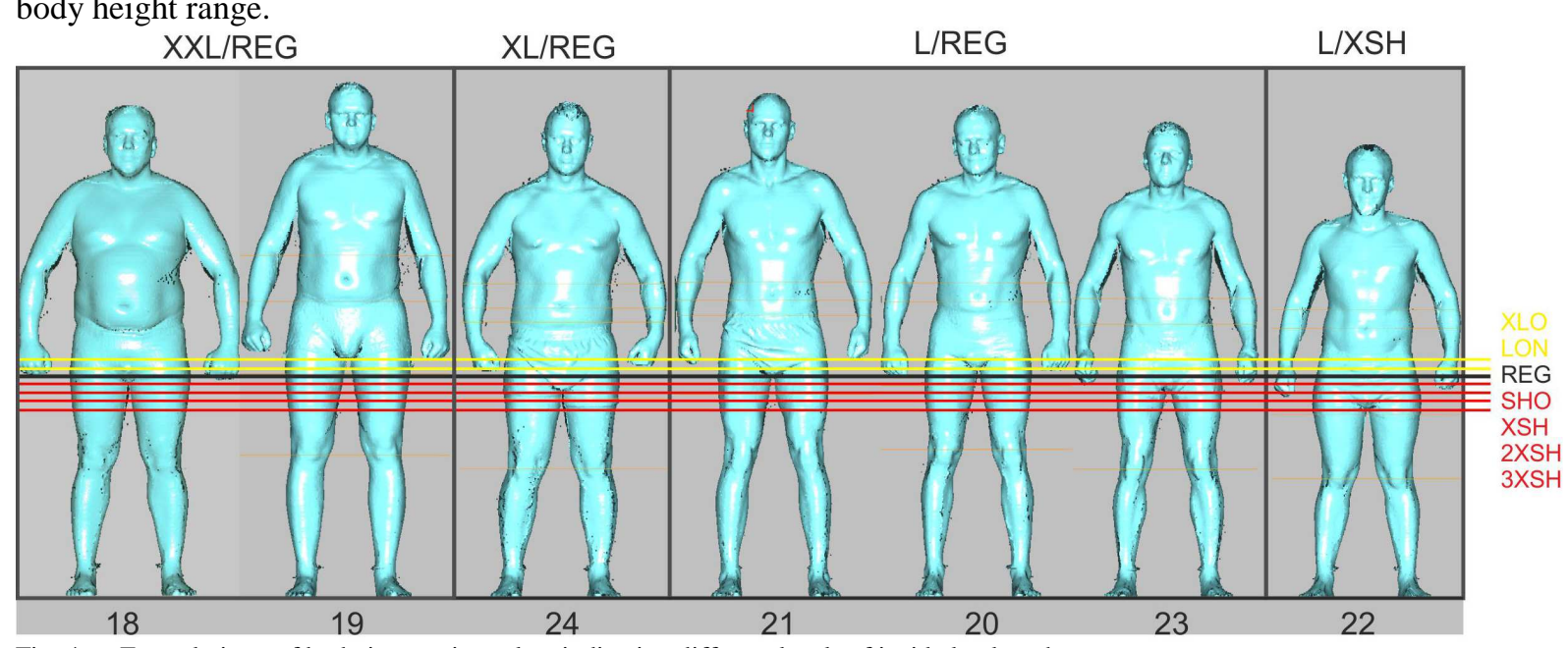

Fig. 4. Frontal views of body images in scale - indicating different levels of inside leg length

As a reference level, inside leg length REG (black line) has been chosen, which refers to test person No. 21, according to all body measurements. It is clear that the remaining persons who also wear trousers of length REG do not refer to this level and distinguishing differences are seen in relation to test person No. 22, who wears trousers of length XSH. Therefore, according to both body measurements, and visually, it should be established that in one size range 
wearers may have different measurements of inside leg lengths.

All this analysis leads to lack of obvious system for choosing uniforms. For clarity, labelling of clothes in accordance with EN 13402-3:2014 [Size Designation of Clothes. Part 3: Body measurements and intervals], interval pictograms supplemented by letter designations may be used (see example Fig.5) [1]. For example, when trying on clothes it would enable products suitable to body measurements to be accurately chosen, provided that the wearer knows their sizes - both the more suitable label and separate body measures.

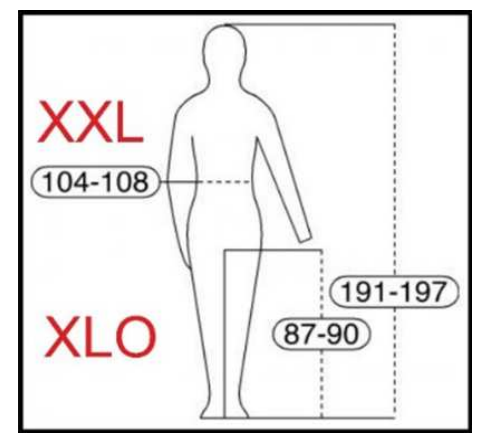

Fig. 5. A label pictogram relevant to test person No.19

Article 25 of the Regulation of the Cabinet of Ministers of the Republic of Latvia No. 519 (09.16.2003) "On Support Conditions, Norms and Procedures by which Soldiers shall be provided with Financial, Material and Technical Resources", it was defined (not effective) as "uniforms are provided according to "sizes" (or body sizes) on the basis of anthropometric measurements. Anthropometric measurements are taken during enlistment, as well as every two years thereafter." However, Article 28 states that: "If anthropometric sizes of soldiers are non-standard... sewing of field uniforms is organised individually" [2]. However, certain instructions in relation to requirements and availability of these standards are not in the normative technical documents of either the Ministry of Defence of the Republic of Latvia or of other uniformed agencies of the Republic of Latvia. Orders of clothes of soldiers are implemented according to developed normal distribution and choice of wear is made by trying on existing delivered products in warehouses.

\section{CONCLUSION}

Sufficient difference shows the necessity to review classification of general sizes, however, it should be taken into consideration that collection and research of body measures of a wider target audience is required as 150 persons measured in the research is an insufficient data set which is unable to clearly demonstrate statistically, anthropometric features of the target population (army and Civil Guard).
In order to credibly demonstrate data of any population a complete overview of the population should be made at the best or a selection should be at least $10 \%$ of all the population subject to review (approximate values, e.g.: $\sim 5000$ army $+\sim 8000$ Civil Guard $=13000,10 \%=1300$ people).

For a general analysis of the population data on body measurements is required before implementing the order in order to duly classify wearers and avoid non-compliance. Moreover, by taking into consideration suggestions that the inside leg length measurement is important for determining a size that is established in the experiment, developed charts may be reviewed by taking the waist circumference as a primary key dimension, but inside leg length and body height (or only inside leg length) - as a secondary, and by classifying lengths of intervals.

It is obvious that by implementing inside leg length as a general secondary measurement the number of sizes, i.e. types of specific test person groups has increased (from 4 to 7 ) that in the case of larger group of people this may affect planning of orders.

As mentioned above, it would be required to develop a database of body measurement values of a target audience in order to make an analysis of and duly plan division of orders. To date, when soldiers enlist, the only information on their body measurements is obtained from the soldiers themselves by asking them about their body height and chest circumference.

\section{ACKNOWLEDGMENTS}

This research work was partially financed by the European Union European Regional Development Fund, through the INTERREG BSR Programme, which awarded a grant to the SWW project (\#R006). The authors gratefully acknowledge the received financial support.

\section{REFERENCES}

[1] EN 13402-2:2014 Size designation of clothes - Part 3: Body measurement and intervals.

[2] Ministru kabineta noteikumi Nr.519, Rīgā 2003.09.16. (prot. Nr.49, 9.§), Noteikumi par apgādes nosacījumiem, normām un kārtību, kādā karavīi nodrošināmi ar finanšu un materiāltehniskajiem līdzekḷiem., 2003 / CM Regulation No.519, Riga 2003.09.16 (Prot.No.49,\$9), Regulations on requirements for supply conditions, rules and procedures for providing soldiers with financial and logistics resources.

[3] LVS EN ISO 20685 Latvijas Standarts 3D skenēšanas metodologijas starptautiski saderīgām antropometrisko datu bāzēm/ 3D scanning methodologies for internationally compatible anthropometric databases. - Brisele : CEN European Committee for Standardization. - ISO 20685:2005.

[4] E Sparks Advances in Military Textiles and Personal Equipment ISBN: 9781845696993, Woodhead Publishing, 2012.

[5] J.C.Tsan-Ming Information Systems for the Fashion and Apparel Industry ISBN: 978-0-08-100571-2, Elsevier, 2016

[6] Šitvjenkins, Igors. Enhancement of the Combat Individual Protection System. PhD Thesis. Rīga: [RTU], 2014. 265 p. 